Seloka: Jurnal Pendidikan Bahasa dan Sastra Indonesia
UNNES (3) (2020): $212-3$
https://journal.unnes.ac.id/sju/index.php/seloka

\title{
The Self-Actualization of the Main Character in the Novel Anak Rantau by Ahmad Fuadi
}

\author{
Indra Putra Pahlewi ${ }^{1 凶}$, Agus Nuryatin $^{2}$, Deby Luriawati $^{2}$ \\ 1. SMA Negeri 1 Ladongi, Kabupaten Kolaka Timur, Provinsi Sulawesi Tenggara. \\ 2. Universitas Negeri Semarang, Indonesia
}

\begin{abstract}
Article Info
Abstract

History Articles

The novel Anak Rantau by Ahmad Fuadi was chosen as the object of research Received: August 2020

Accepted:

September 2020

Published:

31 December 2020 because of the many aspects of self-actualization that are raised in the story, especially regarding the main character's struggles in facing the realities of life and its twists.. The purpose of this research was to describe and explain the process and characteristics of the main character's self-actualization in the novel Anak Rantau by Ahmad Fuadi. This study used a literary psychology approach. The psychological theory used was Abraham Maslow's self-

Keywords: Novel Anak Ranrau, Literary Psychology, Self-Actualization actualization. Hepi started the process of self-actualization since he was abandoned in Tanjung Duren village by his father. Hepi fulfilled 14 traits of self-actualization. The nature of self-actualization that he has was 1) efficient observation of reality; 2) self-acceptance and others as they are; 3) spontaneity, simplicity, and reasonableness; 4) focus on the problem; 5) the need for privacy; 6) function autonomously; 7) appreciation that is always fresh; 8) social awareness/interest; 9) interpersonal relationships; 10) democratic; 11) differences between means and objectives; 12) creativity; 13) independence, and 14) peak experience.
\end{abstract}

\footnotetext{
Correspondence address:

Jalan Halu Oleo No. 8. Kelurahan Welala, Kecamatan Ladongi,

Kabupaten Kolaka Timur, Sulawesi Tenggara

E-mail: putrapahlewi@gmail.com
} 


\section{INTRODUCTION}

Literature as a result of imagination always shows interesting things. One type of literary work that needs to be appreciated for deeper research is a novel.. According to Siswantoro (in Nofrita, 2018: 31), the novel as part of the literary form is the content of reality in which an event and behavior are experienced and done by humans (characters). When describing the character's personality, the author considers many things, including the psychological dimension. Waluyo (2017) states that character from a psychological perspective is the most important main factor in describing the character's personality or temperament. This opinion was clarified by Halimatus Sa'diyah and Nuryatin (2017: 19) who state that the personality of a character is a characteristic that exists in one character.

All the characters featured in the novel are interesting to study. However, as a character who appears more frequently and prioritized, this research focuses more on the main character. Aminuddin (in Juminartanti and Mulyani, 2017: 86), the main character's is a character who has an important role in a story. The main character can be determined from the frequency of appearance in the story, and the instructions given by the author, the character who has the most comments and talks about by the author, and through other characters who have a relationship with the main character (A1Ma'ruf, 2010; Amzar, 2016; Nawawi, 2015; Habiba and Nuryatin, 2018). Through psychological events, the main character can resolve inner conflicts with several reactions (Khunaefi and Nuryatin, (2017: 101-101).

The efforts to understand the characters displayed by the characters in a novel require literary research, both with literature itself and with other sciences. One of the areas of science used to study in literature is psychology. Siswantoro (in Hamdani, 2016: 236) states that even though these two terms are different, they have a common ground, namely departing from humans and life as the source of events. It is in line with Paradida's opinion (in Udayana and
Indiatmoko, 2017: 2019) states that psychology and literature have a functional relationship because they both study the mental state of others. The difference is in the psychology that the symptoms are real, whereas in literature they are imaginative. Purwaningrum and Haryati (2017: 14) conclude that the psychological aspects presented by imaginary figures in literary works can be studied using psychology.

One of the interesting novels to study using literary psychology is the novel Anak Rantau by Ahmad Fuadi. This novel tells of a child named Hepi who is abandoned in his parents' hometown because he has considered having a negative character while living in Jakarta. As a child in the capital city, living far from your parents is a difficult thing. However, Hepi did not give up on the reality he was experiencing. Hepi learned a lot from anything, anytime, and anyone while he was overseas.

The process experienced by Hepi contains a lot of self-actualization. In the theory revealed by Maslow (in Pratika and Dewi, 2014), the use of all talents and the fulfillment of all qualities and capacities in a person is called selfactualization. Maslow (in Feist, Feist, and Roberts, 2017: 282) believes that all humans have the potential to self-actualize.

\section{METHOD}

This research used a theoretical approach and methodological approaches. The theoretical approach used a literary psychology approach. The literature psychology approach used to reveal the self-actualization of the main character in the novel Anak Rantau by Ahmad Fuadi. Besides, this study also used a methodological approach, that was qualitative descriptive. The data in this study were in the form of a text fragment of the novel Anak Rantau by Ahmad Fuadi

The research data were obtained through a literature study and the first level of semiotic reading techniques, namely heuristic reading. The research was continued by analyzing the data using a hermeneutic reading technique. 


\section{RESULT DAN DISCUSSION}

In the results of this research and discussion, fragments of the novel Anak Rantau by Ahmad Fuadi were presented that contains the fulfillment of the hierarchy of needs based on Abraham Maslow's views, as well as descriptions to understand it.

\section{Physiological Needs}

Based on Maslow's view (in Feist, Feist, and Roberts, 2017: 271), the most basic needs of every human being are physiological needs (psychological needs). These needs include the need for food, water, oxygen, maintaining body temperature, and so on. The need for physiology is also found in the main character in Ahmad Fuadi's novel Anak Rantau, Hepi. Hepi is a person whose physiological needs have fulfilled. This can be shown in the following quotation.

"Neneknya sangat memperhatikan ihwal makanannya. Belum lagi nasi di piringnya tandas, sudah disendokkan nasi dan lauk tambahan. Tanpa memandang hari, neneknya rajin pula menyediakan penganan kampung yang sedap seperti bubur kampiun, kolak pisang, kue talam, bika, dan pinukuik untuk cucunya." (Fuadi, 2019: 45)

This quote describes the character Hepi whose food needs have fulfilled. He could easily find it at his grandmother's houseThat is what motivates Hepi to stay at his grandmother's house in Tanjung Durian village. The fragments show that Hepi physiological needs can be seen in the quotation below.

"Setiap kali Hepi menampakkan muka di lapau, Mak Tuo Ros selalu tersenyum lebar dan mengajak dia ke balik bufetnya. "piliah a nan katuju di wa'ang. Pilih apa saja yang kamu suka." (Fuadi, 2019: 46).

From this quote, it can be illustrated that the physiological needs of Hepi were also met when visiting Mak Tuo Ros's lapau. In that place Hepi can choose the food he likes. This also motivates Hepi to be diligent in going to Lapau.

\section{The Safety Needs}

The need for safety (Safety needs) becomes something that motivates after the physiological needs of the individual have fulfilled. These needs include physical security, stability, dependability, protection, and freedom from threatening forces (Maslow in Feist, Feist, and Roberts, 2017: 272).

Since the TV, mic, and charity box belonging to Surau, until his bamboo piggy bank was stolen, Hepi feels it is no longer safe to live in Tanjung Durian. Until Hepi decided to catch the disturbing theft perpetrator. The following quotation can be demonstrated.

"Walau orang-orang tua kita sudah ronda, tetap juga ada pencurian. Mungkin kita perlu ronda sendiri," katanya. Hepi tetap bersikeras untuk membantu kampung." (Fuadi, 2019: 276)

From the quote above, it is illustrated that Hepi struggles to get a sense of security. Apart from himself, Hepi also did this to save his village, Tanjung Durian. The need for security in Hepi can also be shown in the following quote

"Belum pernah Hepi melihat mata dan air mukanya sedingin ini. Entah kenapa bulu kuduknya tegak sempurna, menembus baju kausnya. Hepi berpikir, seriuskah dia dengan perkataannya di kalimat kedua, tidak melihat matahari terbit besok? Tidak boleh hidup?" (Fuadi, 2019: 232)

The quote shows that Hepi needs safety. This happened when Hepi was told by Bang Lenon that he had to be killed. Because of this need, Hepi became motivated to stay alive and was able to arrest Bang Lenon and his gang who were trafficking drugs in Tanjung Durian.

\section{Love and Existence Needs}

According to Maslow (in Feist, Feist, and Roberts, 2017: 272-273), the need for love and existence becomes motivating after physiological needs and security needs are met. This need is also found in Hepi. This can be seen in the following quote

"Tidak pernah selama ini dia secara sadar merasa sedih dan memikirkan penyebab sedih itu. Dia ditinggalkan ibunya, lalu ditinggalkan oleh ayahnya, bahkan Lenon pun meninggalkan dia. Dia hanya ingin mereka kembali." (Fuadi, 2019: 235)

From this quote, it described that Hepi felt abandoned by his closest people, then he told this to Pandeka Luko. That is what motivated Hepi to dare to meet Pandeka Luko and want to return to Jakarta. He wants to get love from the people closest to him. The need for love and 
existence in Hepi is also contained in the following quote

"Diliriknya kakek dan neneknya yang mengangguk-angguk mendengar suaranya. Kalau dia tidak salah lihat, mata mereka berdua berkaca-kaca. Dan itu menghibur perasaannya sedikit. Di sudut lain dia menangkap wajah Ibu Ibet yang memberi dia anggukan. Di sebelah gurunya ini tampak Puti, yang membuat dia malu dan berdebar-debar tak tentu. Sungguh kehadiran mereka berdua menambah obat hatinya." (Fuadi, 2019: 116)

The quote illustrates that Hepi needs love and existence. When other friends who joined Khataman watched by his parents, Hepi was saddest. He has no parents in Tanjung Durian. Hepi needs that. That's why when Hepi saw Grandpa, Grandma, Mother Ibet, and Puti present to support him after hearing the Khatam Khatam, his sadness was relieved.

\section{The Appreciation Needs}

According to Maslow (in Feist, Feist, and Roberts, 2017: 273), the need for love and existence includes self-respect, self-confidence, abilities, and knowledge that are highly valued by others. Hepi, who had previously been motivated to gain a sense of security by catching the perpetrator of the theft, finally succeeded in fulfilling the need for reward. it can be seen in the following quote

"Di pintu surau, Saldi menepuk bahu Hepi.

"Bagus, Hepi. Kalau ada apa-apa selalu kabari ke radio, ya!" (Fuadi, 2019: 275)

The quote illustrates Inspector Saldi praising Hepi. Thanks to the information given by Hepi, the police easily caught the thief. The praise given by Inspector Saldi was a tribute to all that Hepi had done.

\section{Self-Actualization Needs}

Maslow (Feist, Feist, and Roberts, 2017: 274) states that the need for self-actualization includes self-fulfillment, being aware of all selfpotential, and the desire to be as creative as possible. It was also fulfilled in Hepi's character started when he was abandoned by his father to be educated by his grandparents in Tanjung Duren Village.
"Nak, tidak usah berkemas. Ayah sudah daftarin kamu sekolah SMP di sini" (Fuadi, 2019: 49)

What happened to Hepi was certainly something that shook the soul. Hepi feels devastated by the fate that befell him. Even so, Hepi didn't want to give up. He was determined to make money so he could return to Jakarta with the money he made himself. It can be shown in the following quotation

"Dia bertekad akan membuktikan ke ayahnya bahwa dia bisa mencari uang untuk membeli tiket ke Jakarta. Kalau perlu dia akan merangkak melata untuk mencari uang. Dia bahkan bertekad untuk mengumpulkan uang tidak sekadar untuk tiket bus, tapi tiket pesawat. Dia belum tahu caranya, tapi dia akan membanting tulang untuk mencarinya" (Fuadi, 2019: 59).

The fulfillment of the need for selfactualization of the character Hepi in the novel Anak Rantau began when he decided to stay in Tanjung Durian and promised to raise money to return to JakartaIn the process, Hepi survives from the difficult time when abandoned by his father. Apart from that, Hepi also managed to grow spiritually and realized his potential.

\section{The Self-Actualization of the Main Character in the Novel Anak Rantau}

Based on the view of Abraham Maslow. The characteristics of self-actualization include: 1) efficiently obervasion of reality; 2) selfacceptance and others as it is; 3) spontaneity, simplicity, and reasonableness; 4) focus on the problem; 5) the need for privacy; 6) function autonomously; 7) appreciation that is always fresh; 8) social awareness/interest; 9) interpersonal relationships; 10) democratic; 11) differentiate between means and objectives; 12) creativity; 13) independence, and; 14) high experience. (Schultz, 2020: 98-111).

\section{Efficinetly Observasion of Reality}

The nature of observing in reality and efficiently will make a person able to recognize lies, cheating, and falsehood by others, and to be able to analyze critically, logically, and deeply of all-natural and life phenomena (Maslow in Schultz, 2020: 99). As the main character, Hepi was able to recognize what other people are 
showing, such as self-actualized. It can be seen in the following quote

"Mata kakeknya tampak mendelik, tapi di balik kumis tebal yang memutih itu, Hepi melihat sebuah senyum terbit untuk dia. (Fuadi, 2019: 20)

From the quote above, it is illustrated that Hepi witnessed his grandfather's smile when Hepi kissed his grandfather's hand. Hepi recognizes that what his grandfather showed him was only to cover up his hospitality. His grandfather wasn't that fierce. Also, Hepi has always been an objective observer. He didn't believe in stories that were hard for common sense to accept. It can be seen in the following quote

"Sebetulnya Hepi tidak terlalu percaya kabar iniitu tentang Pandeka Luko karena tidak masuk logikanya." (Fuadi, 2019: 219)

Hepi doesn't believe the story about Pandeka Luko, who is said to have black magic, a sorcerer, can double the money, only goes out at night to catch bats and eat them. According to him, such stories exist only in fairy tales. He was sure that such a thing did not exist in reality.

\section{Self-acceptance and others as it is}

Self-actualized can accept themselves without complaining, be it their weaknesses and strengths. Good self-acceptance makes them present themselves as they are, without pretense, defensive nature, or hiding behind social roles (Maslow in Schultz, 2020: 100). Hepi has a nature that does not complain about the fate that must live. It can be seen in the following quote.

"Hepi mengatupkan telapak tangannya ke muka. Mimpinya pulang ke Jakarta dengan segera benar-benar karam. Tiada jalan lain, dia harus mengulang lagi dari nol." (Fuadi, 2019: 295-295)

Hepi also shows an apologetic attitude when making mistakes. It was illustrated when he made a mistake when he delivered an order for goods from Bang Lenon's customer, he apologized to Bang Lenon. It is shown in the following quote

"Maafkan, Bang, tidak akan diulangi. Maaf," kata Hepi sampai terbungkuk-bungkuk. (Fuadi, 2019: 155)

\section{Spontaneity, simplicity, dan reasonableness}

Maslow (in Schultz, 2020: 100-101) states that self-actualized are individuals who behave openly and directly without pretending. They can show their emotions honestly. Hepi's spontaneous and unreasonable nature when Ibet's teacher was scared to see a snake coming out of Zen's pocket, Hepi showed his emotions suddenly. Not only kicked Zen out because it scared Mrs. Ibet but she also spontaneously reached out to help Mrs. Ibet get out of her place. It can be seen in the following quote

"Hepi menghambur ke depan, berteriak keras sembari mengibas-ngibaskan tangan ke arah Zen yang merasa tidak bersalah. "Keluar wa'ang sekarang!" Dia menghardik Zen." (Fuadi, 2019: 88)

Likewise, when Hepi saw his grandfather who was sad because of the surau being lonely. When Hepi shows his attitude spontaneously and without making up. He suddenly said that he would continue to accompany his grandfather in the surau. It can be shown in the following quote

"Jangan iba hati, Kek. Kalaulah semua orang lari, ada Hepi yang akan ikut kakek terus di surau." Hepi terkejut sendiri mendengar kalimat yang manis sekali terlompat begitu saja dari mulutnya." (Fuadi, 2019: 168)

\section{Focus on the Problem}

Self-actualizing people were generally very focused on issues outside of themselves or focused on problems and not on the egoThey were aware of a task or mission that must be carried out in life, in where to do so, they must pull all their energy (Maslow in Schultz, 2020: 102-103). Hepi was depicted as being aware of the important tasks that he should be lived. It can be seen when Hepi saves the remaining money he gets to fulfill his dream of returning to Jakarta. It can be seen in the following quote

"Hepi menahan diri untuk belanja dan memasukkan semua amplopnya ke tabungan bambu." (Fuadi, 2019: 118)

Also, Hepi shows the nature of realizing that the other tasks must be carried out in his life. It showed when his village was shocked by cases of theft and drug trafficking, Hepi puts all his energy into carrying out investigations to find thieves and chasing drug dealers who are 
troubling his village residents. It showed in the quote below

"Mereka bertiga lalu membagi tugas piket untuk meronda pakai teropong. Hepi mengingatkan kawan-kawannya. "Ingat, ya! Semua yang kita lihat aneh, awasi dan catat!" (Fuadi, 2019: 277)

\section{The Privacy Needs}

Maslow (in Schultz, 2020: 103-104) is of the view that self-actualizing people need privacy to determine what attitudes and actions to take. Hepi was a person who needs privacy to determine the attitudes and actions he should take. He needs the solitude to think and reflect when his mind is tired. It showed in the following quote

"Hepi meluruskan badan dan menarik selimut sampai dada, dia tidak bisa langsung pulas. Dia menatap langit-langit surau itu dan melihat nasibnya yang remang kelabu. (Fuadi, 2019: 141)

When Hepi spends his time raising money by working for Lenon and Mak Tuo Ros, Hepi seems to distance himself from his two friends. The decision was unanimous to collecting the money by working like anything. His decision was not swayed by the persuasion of his friends. It showed in the following quote

"Pertemanan kita tetap. Aku tidak berubah. Aku Cuma marah ke Ayah, dan ingin mengumpulkan uang lebih cepat. Karena itu aku perli bantu Bang Lenon dan Mak Tuo Ros." (Fuadi, 2019: 141)

\section{The Autonomously Functions}

People who have achieved selfactualization do not depend on the environment. He can do anything and anywhere without being influenced by the environment (situations and conditions) that surround him (Maslow in Koeswara, 2001). Hepi was an autonomous person. He does not depend on others. It was reflected when he was willing to do anything and anywhere to make his dream come true for Jakarta. An illustration of Hepi functioning autonomously can be seen in the following quote

"Sejak saat itu mereka bertiga menjadi pembantu umum, bertugas apa saja, mulai dari menyapu, membersihkan meja, mengantar pesanan, hingga mencuci piring." (Fuadi, 2019: 92)
From the quote above, it is illustrated that to get money to return to Jakarta, Hepi has to work as a general servant at Mak Tuo Ros's lapau. Money from the work he collected little by little. Not only working as a general assistant, but Hepi also worked as a courier for Bang Lenon. It showed in the following quote

"Mulai hari ini aku kasih kepercayaan kau lebih banyak. Kau diangkat menjadi kurir, pengantar dagangan aku ke pembeli." (Fuadi, 2019: 143)

\section{Appreciation is alyaws fresh}

Self-actualized always value certain experiences with feelings of happiness, fascination, and awe, even though they are repeated every day and are not even noticed by most people. (Maslow in Schultz, 2020: 104). The embodiment of Hepi as an actualizes who is always fresh in appreciation can be seen in the following quote

"Hepi senang duduk-duduk sembari mengayun kaki bersama ayahnya di lapau itu karena bisa menguping ota atau obrolan hilir mudik bapakbapak. Setiap mendengar diskusi mereka, dia merasa semakin pintar dan lebih dewasa. Di lapau ini dia semakin tahan berlama-lama karena selalu ada koran singgalang, Padang ekspres, Haluan, dan sesekali koran dari Jawa." (Fuadi, 2019: 46)

When his father took him to Mak Tuo Ros's lapau, he liked the experiences in the lapau. He appreciates the event with joy and is fascinated by the conversation that took place in lapau as it makes him more and more aware. In Lapau there were various newspapers that he could read. The same thing Hepi showed in other events. It showed in the quote below.

"Dia mendekat ke Hepi, lalu menepuk-nepuk bahunya, "Lumayan," katanya dengan napas masih ngik-ngok. Lubang hidung Hepi rasanya kembang-kempis, senang juga sesekali dipuji kakeknya. Dia merasa keren sekali suaranya bisa menguasai desa." (Fuadi, 2019: 40)

When he replacing his grandfather for the call to prayer in the surau. Hepi was very happy to get praise from his grandfather. It was a new experience for him. He felt very cool when his voice was heard throughout the village. He appreciated the experience with feelings of pleasure and pride. 


\section{Social awareness/interest}

The soul of a self-actualizing person has filled with empathy, compassion, compassion, and wanting to help others. This urge will raise social awareness where he has a sense of belonging and helping others (Maslow in Schultz, 2020: 107). Hepi was a person who has a strong sense of empathy. It showed in the following quotation

"Dia semakin bisa berempati begitu ingat uang yang dicuri juga adalah gaji dia." (Fuadi, 2019. 203)

When Hepi found Mak Tuo Ros sluggish because the money in his lap has been burglarized, Hepi has empathy for Mak Tuo Ros. He became more empathetic when he learned that what the thief had stolen was his salary. Hepi's description of empathy can also be seen in the following quote

"Hepi segera mengambil HT di surau. Lalu dia putar gelombang yang pernah disebutkan Inspektur Saldi. "Alfa juliet di sini. Bisa dikopi?" (Fuadi, 2019: 203)

The empathy that Hepi showed to Mak Tuo Ros was not only limited to empathy but also followed by a desire to help. When Mak Tuo Ros no longer knew what to do, Hepi offered Mak Tuo Ros to report the incident. Mak Tuo Ros, who heard the offer, immediately agreed, then Hepi reported the incident to the police through his handie talk.

\section{Interpersonal Relationship}

According to Maslow (in Schultz, 2020: 107-108), the interpersonal relationship of selfactualizing people is deep and strong. People who can self-actualize tend to have good relationships with other people. Interpersonal relationships that exist in Hepi it showed in the following quote

"Sisanya dibagikan ke Attar dan Zen yang berjingkrak senang. "Ini untuk kalian berdua, aku bisa beli lagi nanti di Jakarta," katanya. (Fuadi, 2019: 49)

Towards the day of his return to Jakarta, Hepi gave some of his toys to Attar and Zen. He did this because he felt that he was already attached to his two friends. Giving is a form of love for others. Not based on any tendency.
"Wa'ang jauh-jauh tinggal di kampung tidak untuk bergaul dengan preman." Suara kakeknya terdengar geram. Wajahnya keruh. Nenek memandanginya dalam-dalam dengan wajah khawatir". Tapi Bang Lenon itu preman tobat, Kek. Sudah mulai sering ke surau." (Fuadi, 2019: 81)

Hepi has a good relationship with everyone. Including Bang Lenon. Even though his grandfather forbade him to hang out with Lenon who had a thug background, he remained friends. Moreover, Lenon seemed to have realized that he had often come to worship at the surau.

\section{Democratic}

In their daily lives, self-actualizing people do not just tolerate others. They allow and accept all people regardless of social class, educational level, political or religious rank, race or color. They do not look down on others who have less intelligence and abilities than themselves. Self-actualizing people are ready to learn about everything from anyone (Maslow in Schultz, 2020: 108-109). This democratic character also appears in the person of Hepi. Especially the Hepi character who doesn't underestimate others and is ready to learn about anything from anyone. These characters can be seen in the quote below

"Yang agak menarik perhatiannya di sekolah saat ini hanya pelajaran sejarah dari Ibu Ibet. Guru yang satu ini tampaknya punya pengetahuan di luar batas mata pelajaran." (Fuadi, 2019: 86)

When Mrs. Ibet gives history lessons in her class, Hepi is amazed by Ibu Ibet's abilities. The new teacher can tell you anything related to history. Therefore, Hepi is enthusiastic every time Mrs. Ibet comes in to give lessons.

"Dalam hatinya tumbuh cita-cita untuk mengitari dunia pula suatu saat kelak. Dia ingin belajar ke mana saja, kepada siapa saja, dan kepada apa saja. Seperti Chinmi. Alam terkembang jadi guru." (Fuadi, 2019: 86)

When Mrs. Ibet talked about the migration of humans from Africa to Asia to Indonesia, Hepi paid so much attention to this explanation; he was even determined to go around the world more than ancient humans. Hepi wants to study anywhere, to anyone, to 
anything. Like the Chinmi character in his favorite Kung Fu Boy story.

\section{Differences between means and objectives, between good and bad}

For actualized people, goals or ideas are more important than the means used to achieve them (Maslow in Schultz, 2020: 109). This is also seen in Hepi. Even though the work he did was unlike any other established job, Hepi continues to carry out these jobs to achieve the desired goals. This is illustrated in the following quote

"Gaji mereka bekerja seharian adalah makan sepuasnya dan uang sepuluh ribu rupiah." (Fuadi, 2019: 93)

For the sake of getting money to buy plane tickets to Jakarta, Hepi does anything. One of them is by working as a waiter at Mak Tuo Ros's lapau. In the previous explanation, we have also mentioned Hepi who also works as an assistant and delivery courier for Bang Lenon's goods. It showed in the following quotation

"Setelah agak jauh dari Bang Lenon, cepat-cepat dia periksa isi sakunya. Ada selembar uang sepuluh ribu untuk pekerjaan yang hanya setengah jam. Malam itu dengan sukacita dia selipkan uang ini ke tabungan betungnya." (Fuadi, 2019: 146)

\section{Creativity}

Self-actualizing people have a prominent feature of being creative people. They are original, inventive, and innovative. They can put forward extraordinary ideas, but also they understand that there will be some of their ideas that cannot realize (Maslow in Schultz, 2020: 110). The description of the character of creativity in the Hepi character is shown in the following quote.

"Kenapa kita tidak punya markas sendiri?" kata dia kepada kedua kawannya. (Fuadi, 2019: 174)

While at the surau, Hepi came up with the idea of establishing a headquarters. The base that was established used to monitor anything around the surau. Including to see the headquarters of Lenon and his people who have underestimated them.

"Nah, kau masih tidak percaya juga setelah kakek yang cerita sendiri?" ledek Zen. Semakin dianggap daerah terlarang, semakin baik kubah itu jadi markas kita. (Fuadi, 2019: 180)

From the quote above, it can be illustrated that Hepi is a creative person in raging ideas.

\section{Independence}

In his view, Maslow (in Schultz, 2020: 103-104) reveals that self-actualizing people can maintain their stance and the decisions they make. Not shaken or affected by various shocks or interests, never doubting between right and wrong (Maslow in Schultz, 2020: 103-104). Hepi was also a person who maintains his position. It showed in the following quote.

"Kalau perlu, tangan aku sendiri yang akan menangkap pencuri ini," katanya sambil mengepalkan tangan kuat-kuat. (Fuadi, 2019: 270)

When Hepi finds out that his bamboo piggy bank was being stolen by the thief, he decides to arrest the thief, even though Attar and Zen try to persuade him to leave the thief's business to the police and adults. It showed in the quotation below

"Aku tidak akan menunggu orang lain menemukan pencuri, aku akan memburu mereka sendiri," katanya". (Fuadi, 2019: 271)

\section{High experiences}

According to Maslow (in Setyowati, 2017: 177) actualized who have had peak experiences are honest, sincere, unpretentious, sincerely, and open. Hepi who has been abandoned by his father sincerely and courageously opens up to convey that he has forgiven his father's mistakes. This attitude proves that Hepi was an actualized person. It showed in the following quotation.

"Sudah aku maafkan," katanya singkat, bagai terloncat begitu saja dari mulutnya." (Fuadi, 2019: 353-354)

\section{CONCLUSION}

Based on the analysis that has been done, it concluded that Hepi fulfills the hierarchy of needs based on Abraham Maslow's view. Hepi's self-actualization process began when his father left him in Tanjung Duren village. When that event arrives, Hepi must use all of his potentials to survive and also answer his father's challenge 
to return to Jakarta by earning his own money. Hepi has 14 self-actualizing properties. The nature of self-actualization that he has is 1) efficiently obervasion of reality; 2 self-acceptance and others as it is; 3 ) spontaneity, simplicity, and reasonableness; 4) focus on the problem; 5) the need for privacy; 6) function autonomously; 7) appreciation that is always fresh; 8) social awareness/interest; 9) interpersonal relationship; 10) democratic; 11) deferences between menas and objective; 12) creativity; 13) independence, dan: 14) high experiences.

Suggestions for researchers, this research can be used as a reference and guidelines in conducting a research. This research can also be developed further, both in terms of the analysis of figures such as additional figures, as well as in terms of the analytical approach used. For literary lovers, this research can be used as a reference for literature reading.

\section{REFERENCES}

Alimatussa'diyah \& Nuryatin, A. (2017). "Inferioritas tokoh perempuan dalam novel

bumi cinta karya habiburahman el shirazy". Seloka: Jurnal Pendidikan Bahasa dan Sastra Indonesia, 6 (1), hlm 15-24.

Feist, J., Feist, G, J., Roberts, T. (2017). Teori kepribadian. Jakarta: Salemba Humanika.

Fuadi, A. (2019). Anak rantau. Jakarta: PT Falcon Interactive.

Habiba, S, P, A. \& Nuryatin, A. (2018). "The islamic values representations of female main character in novels by habiburrahman

el-shirazy". Seloka: Jurnal Pendidikan Bahasa dan Sastra Indonesia, 7 (1), hlm. 6066.

Hamdani, A. (2016). "Drama "malam jahanam" karya motinggo busye: sebuah telaah psikologis". Bahasa dan Sastra: Journal of Language and Literature Education, 16 (2), hlm. 235-245.
.Juminartanti, D. (2017). "Aktualisasi Diri Tokoh

Utama Pria dalam Novel Trilogi Makrifat Cinta Karya Taufiqurrahman Al-Azizy". Seloka: Jurnal Pendidikan Bahasa dan Sastra Indonesia, 6 (1), hlm. 85-92.

Khunaefi, A. \& Nuryatin, A. (2017). "Peristiwaperistiwa kejiwaan dan reaksi tokoh utama selama menghadapi konflik perubahan kepribadian dalam novel cinta di ujung sajadah karya asma nadia". Lingua: Jurnal Bahasa dan Sastra, 13 (1), hlm. 100-108.

Nofrita, Mirsa. (2018). "Karakter tokoh utama novel sendalu karya chavchay syaifullah". Jurnal Kata: Penelitian tentang Ilmu Bahasa dan Sastra, 2 (1), hlm. 30-36.

Pratika, E. \& Dewi, N. W. S. P. (2014). "Aktualisasi diri dan persepsi terhadap pelaksanaan pelatihan pada karyawan PT pelindo". Jurnal Psikologi Teori dan Terapan, 5 (1), hlm. 7-14.

Purwaningrum \& Haryati, N. (2016) "Pengaruh pola asuh permisif terhadap perkembangan kepribadian tokoh utama novel Mendung Tak Bermalam karya abu umar basyier: kajian psikologi sastra". Lingua: Jurnal Bahasa dan Sastra. 12 (1), hlm. 13-24.

Schultz, D. (2020). Psikologi pertumbuhan: modelmodel kepribadian sehat. Yogyakarta: Kanisius.

Setyowati \& Supriyanto, T. (2017). "Proses aktualisasi diri tokoh utama dalam dwilogi novel padang bulan dan cinta di dalam gelas". Seloka: Jurnal Pendidikan Bahasa dan Sastra Indonesia, 6 (1), hlm. 169-178.

Udayana, H. \& Indiatmoko, B. (2017). "Ekspresi

Cinta dan Citra Religius dalam Novel Atheis Karya Achdiat Kartamihardja". Seloka: Jurnal Pendidikan Bahasa dan Sastra Indonesia, 6 (2), hlm. 218-225. .

Waluyo, Herman, J. (2017). Pengkajian dan apresiasi prosa fiksi. Yogyakarta: Ombak. 